\title{
Apprehending the potential of BABY BOOM transcription factors to mitigate cotton regeneration and transformation
}

\author{
YAVUZ Caner, TILLABOEVA Shakhnozakhan and BAKHSH Allah ${ }^{*}$ (1)
}

\begin{abstract}
Since the advent of transgenic technology, the incorporation of gene(s) encoding traits of economic importance in cotton is being practiced worldwide. However, factors like recalcitrant nature of cotton cultivars, in vitro regeneration via tissue culture (especially via somatic embryogenesis), genotype dependency, long and toilsome protocols impede the pace of development of transgenic cotton. Besides that, types and age of explants, media composition, plant growth regulators and other environmental factors affect in vitro cotton regeneration significantly. The studies of genetic control of in vitro regeneration in plants have elucidated the role of certain transcription factor genes that are induced and expressed during somatic embryogenesis. Among these transcription factors, BABY BOOM (BBM) plays a very important role in signal transduction pathway, leading to cell differentiation and somatic embryos formation. The role of BBM has been established in plant cell proliferation, growth and development even without exogenous growth regulators. This review intends to provide an informative summary of regeneration and transformation problems in cotton and the latest developments in utilization of BBM transcription factors in cotton. We believe that the use of BBM will not only ease cotton genetic improvement but will also accelerate cotton breeding programmes.
\end{abstract}

Keywords: Cotton, Genetic manipulations, Regeneration and transformation, BBM

\section{Background}

Cotton (Gossypium hirsutum L.) is the most important cash crop and the backbone of textile industry in the world. Globally, cotton is grown in 75 countries/regions and significantly improves the economies of many countries through the provision of fiber, oil, and several other products. The most important products of cotton include garments, gloves, mufflers, bags, socks, jackets, beds, vegetable oil, curtains, bed sheets, and others (Bakhsh et al. 2016; Jabran et al. 2019).

Cotton breeders face serious challenges as cotton is heavily infested by a number of sap-sucking and chewing insect pests that causes significant yield losses. Besides

\footnotetext{
*Correspondence: abthebest@gmail.com; allah.bakhsh@nigde.edu.tr Department of Agricutlural Genetic Engineering, Faculty of Agricultural Sciences and Technologies, Nigde Omer Halisdemir University, 51240 Nigde, Turkey
}

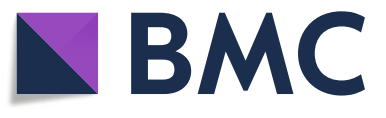

() The Author(s). 2020 Open Access This article is licensed under a Creative Commons Attribution 4.0 International License, which permits use, sharing, adaptation, distribution and reproduction in any medium or format, as long as you give

appropriate credit to the original author(s) and the source, provide a link to the Creative Commons licence, and indicate if changes were made. The images or other third party material in this article are included in the article's Creative Commons licence, unless indicated otherwise in a credit line to the material. If material is not included in the article's Creative Commons licence and your intended use is not permitted by statutory regulation or exceeds the permitted use, you will need to obtain permission directly from the copyright holder. To view a copy of this licence, visit http://creativecommons.org/licenses/by/4.0/ that, bacterial and fungal diseases, salinity and drought regimes also affect cotton yield and yield related traits (reviewed in Bakhsh et al. 2015). The plant breeders have continuosly contributed to the improvement of cotton using conventional as well as modern methods. However, the lack of resistance to pests and diseases in available germplasm halts the developments of new cultivars (Jabran et al. 2019; Khabbazi et al. 2018).

Biotechnology has been essential for the acceleration of crop improvement over the last two decades. Two of the most impactful biotechnology-derived traits are insect resistance and herbicide tolerance. The use of biotechnology and introduction of these traits has greatly contributed to the increase of agricultural productivity and stabilization of food security worldwide (Mall et al. 2019). Genetically-modified (GM) cotton is the first non-food transgenic crop that has provided a specific, 
safe and effective tool against lepidopterous pests $(\mathrm{Wu}$ and Guo 2005). Growers' satisfaction of transgenic cotton is largely due to several significant benefits, such as lower production costs, streamlined yet flexible management, and a reduced impact on the environment (Wilkins et al. 2000).

Hence, the most significant breakthrough in plant biotechnology is the development of the techniques to transform genes from unrelated sources into commercially important crop plants. However, genetic transformation protocols are not standardized, and highly dependent on genotypes and have long duration of cotton regeneration. In order to obtain successful transformation, numerous protocols have been examined, such as Agrobacterium-mediated transformation (Firoozabady et al. 1987; Umbeck et al. 1987), transformation through meristem (Gould and Magallanes-Cedeno 1998), particle gun bombardment (Finer and McMullen 1990). In these protocols, factors like recalcitrant nature of cotton cultivars, regeneration via tissue culture, laborious and time consuming protocols delay the pace of transgenes development in cotton.

Protocols of meristem transformation allow generating a high number of chimeras and have unique feature of genotype independent transformation. Because the number of meristematic cells is restricted, the survived cells within regenerated tissues are even less., Therefore the quantity of plants responding to the transgenic selection is low (Firoozabady et al. 1987; Sunilkumar and Rathore 2001). However, the process is still laborious and the ability of cultivars to regenerate multiple shoots and branching affect the duration of detecting transformants (McCabe and Martinell 1993; Keller et al. 1997). In this situation, the next generation only shows success of transformation (John 1997). Contrarily, after establishing, embryogenic lines can be regularly subcultured and applied for numerous transformations with advantage of short culturing time, successfully converting more transformants into regenerated plantlets (Leelavathi et al. 2004).

The signaling pathways and several other diverse cellular functions in plants are carried out by certain transcription factors. Among these, BABY BOOM (BBM) transcription factor of AP2/ERF family is an important regulator of cell totipotency and plays a key role in cell proliferation, growth and development (Jha and Kumar 2018) as revealed in Fig. 1 as well. The studies of genetic control of in vitro regeneration in plants have elucidated that these transcription factor genes are induced and expressed during somatic embryogenesis (SE). This review intends to provide an informative summary of regeneration and transformation problems in cotton and the latest developments in utilization of BBM transcription factors in different species with special focus on cotton. We believe that the use of BBM will not only ease cotton genetic improvement but will also accelerate cotton breeding programmes.

\section{Somatic embryogenesis and cell proliferation}

Cotton is one of the major economically important crops which produces numerous materials, whereas natural fibre and oil from the cottonseed are the most widely used products. The genus Gossypium is a member of Malvaceae family whearas its 54 species are grown on tropical and subtropical parts of the world (Jabran et al. 2019). Nowadays the most produced cotton cultivars are Gossypium hirsutum (90\%) followed by Gossypium barbadense and two rarely grown Asiatic cotton varieties Gossypium arboreum and Gossypium herbaceum (Rajasekaran 2004).

There are several problems associated with cotton management caused by different environmental stresses affecting production. Severe attack from insects and various stresses lead to the high losses of yield and quality of the lint. These difficulties can be eliminated in some way with the help of genetic improvement but it is limited by long period of time and lack of necessary variation, especially for pest resistance (Khan et al. 2011). Several conventional breeding techniques offer useful strategies such as plant tissue culture, but it needs a system for high regeneration from cotton somatic cells (Rajasekaran 2004).

In vitro culture is done for physiological and genetic developments but there is no standardized method due to quite difficult induction. In comparison with other major crops, cotton has difficulty in somatic embryogenesis and a lot of elite varieties are considered as recalcitrant (Kumria et al. 2003). Somatic embryogenesis is considered to be more valuable than organogenesis method due to single cell origin of regenerates and possibility of easier in vitro regulation of somatic embryos due to absence of vascular connection with the maternal tissue (Shoemaker et al. 1986). Despite the fact that cotton crop is quite stress resistant, sub-optimal environment affects on cotton boll development and it was established that most of the crops cultivated can reach only $50 \%$ of its potential because of abiotic stress (Boyer 1982). Most of the genetic improvements that have been done in the cotton crop were emphasized to improve the cotton lint, but the changes are insignificant and it reached plateau effect (Kumria et al. 2003).

There are several important issues related to the development and obtaining of transgenic cotton which requires highly efficient methodology for transformation and further regeneration of plants. The regeneration methodology of the cotton crop is still challenging in comparison with other crops 
$\mathrm{a}$

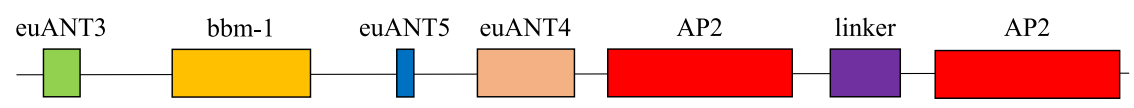

[GLSMIKTWLR(N/S)Q]
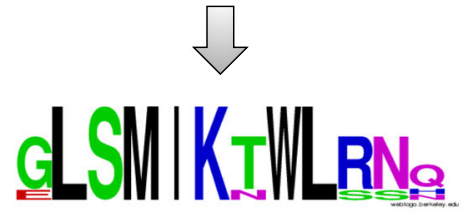

b
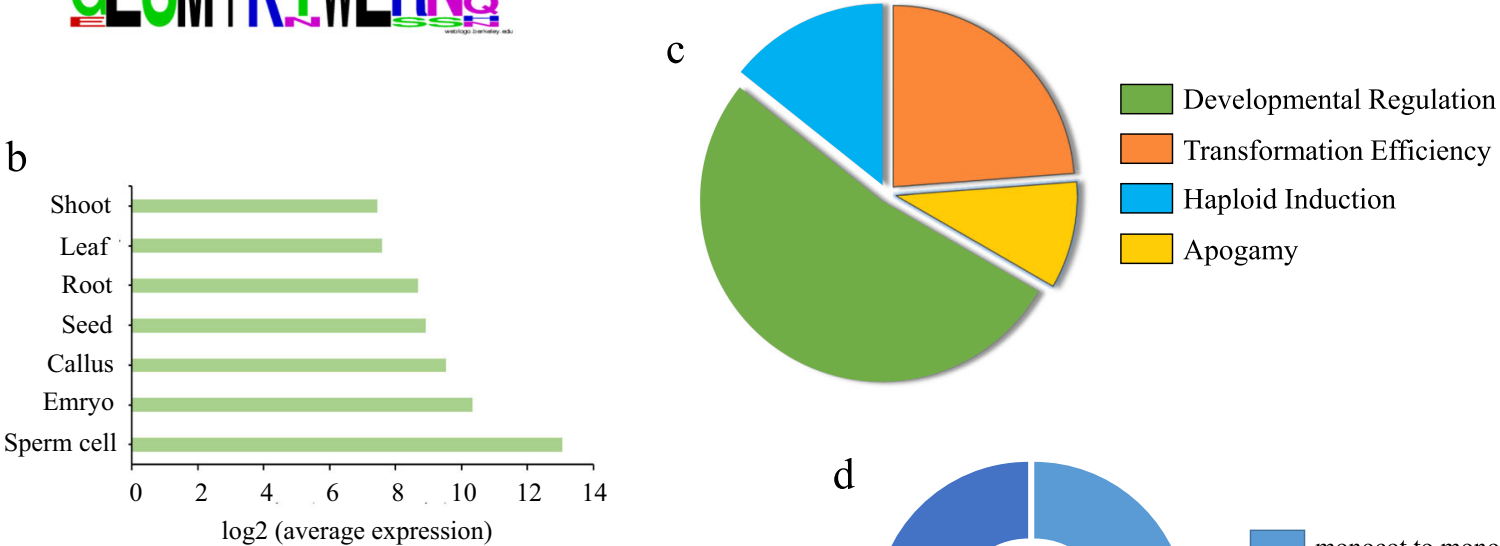

d

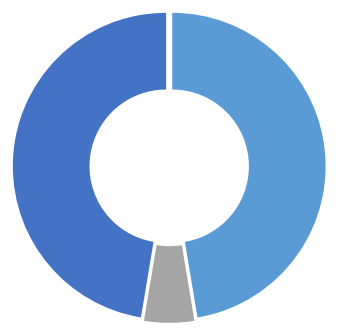

monocot to monocot

e

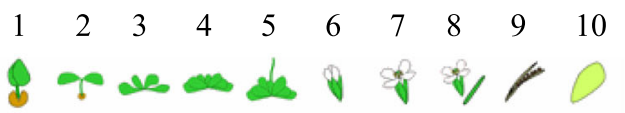

Number of samples

$\begin{array}{llllllllll}515 & 2785 & 842 & 2210 & 369 & 720 & 1038 & 274 & 93 & 18\end{array}$

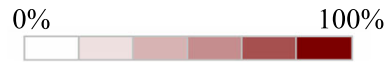

Percent of Expression Potential

Fig. 1 a domains in BBM gene and the amino acid sequence of bbm-1 motif along with sequence logo, $\mathbf{b}$ tissue specific expression and developmental regulation of AtBBM gene (Arabidopsis thaliana), $\mathbf{c}$ the classification of studies for BBM genes (BBM1 and BBM2) and the distrubution of the subjects into four main categories: developmental regulation, transformation efficiency, haploid induction and apogamy, $\mathbf{d}$ fern, monocot and dicot classification of BBM studies. 1: germinated seed, 2: seedling, 3: young rosette, 4: developed rosette, 5: bolting, 6: young flower, 7: developed flower, 8: flowers and siliques, 9: mature siliques, 10: senescence

(Sakhanokho and Rajasekaran 2016). Extremely low regeneration and efficiency of somatic embryogenesis and somaclonal variation have a very high effect on research and usually time-consuming. There have been numerous works on increasing the regeneration and inducing somatic embryogenesis to remove somaclonal variation (Wilkin et al. 2004). Numerous researches on embryogenesis and regeneration of cotton plant encountered the most common problems of the cotton crop, i.e., high percentage of abnormal somatic embryos, extremely low level of embryo induction, high phenolic activity, poor condition of embryos and low levels of plantlet survival (Duncan 2010; Kumria et al. 2003; Duncan 2010; Zhang 2015).

\section{The process of plant embryogenesis}

Somatic embryogenesis can be induced by several factors by changing molecular and physiological mechanisms. Different conditions as exogenous application of plant hormones, culture conditions, content of medium, wounding of explants, application of stress, the age, genotype and type of explants, and cell density all cause differentiation in cell molecular pathway (Pencik et al. 2015; Loyola-Vargas and Ochoa-Alejo 2016). Moreover, concentration and the source of nitrogen are considered as one of the crucial elements of somatic embryogenesis induction (Reinert et al. 1967).

Embryogenesis of higher plants can be divided into two specific phases, i.e., early and late morphogenetic 
processes (Méndez-Hernández et al. 2019), where early processes start development of embryonic cells, tissues and organs and late processes allowing cells to enter the metabolic state (West and Harada 1993; Goldberg et al. 1994). During embryogenesis, embryo can be developed from a zygote or from somatic cells of the plant, where zygote is formed from fusion of gametes and somatic embryogenesis is the result of vegetal tissues growth (Loyola-Vargas and Ochoa-Alejo 2016). Somatic embryogenesis can be induced through in vitro conditions, apomictic embryogenesis and naturally several plants form somatic embryos in response to stress (Garcês and Sinha 2009). Somatic embryogenesis is a complex process that involves different signaling pathways that regulate gene expression patterns in response to stress conditions, exogenous application of hormones and eventually represent totipotency (Nic-Can and LoyolaVargas 2016). Somatic embryogenesis can occur in direct and indirect pathways, having formation difference in the way and place of somatic embryos (Quiroz-Figueroa et al. 2006).

The special order of cell growth and division, enlargement and two axes differentiation are the bases of higher plants growth. Investigation of embryogenesis in plants became easier with genetic approaches and methods like investigating abnormal embryogenesis by isolating and marking of mutants and further characterization of similar genes and their functions (Abid et al. 2010). Numerous analyses of embryogenesis in dicotyledons led to hypothesis of three domains (apical, central and basal) embryo development (Laux et al. 2004). According to this hypothesis, shoot meristem is generated from the apical part, hypocotyl and roots are formed from the central part of the embryo and the basal domain gives rise to the root meristem distal parts and central root cap of stem cells. It is known that embryogenesis forms two different cell lines, the shoot apical meristem (SAM) and the root apical meristem (RAM) (Abid et al. 2010).

The new cells formed from somatic cells have regeneration capacity and can form fertile plant. Somatic embryos of gymnosperms have specific suspensor system, while angiosperms have reduced or deficient suspensors due to deficient hypophyseal cell (Smertenko and Bozhkov 2014). Molecular pathways of somatic embryo formation remained unclear and it was established that auxin distribution is necessary for initiation of embryo formation and the asymmetrical movement of auxin arises from differential transport (Márquez-López et al. 2018). It was observed that zygotic embryogenesis caused asymmetric division of cells and forms two groups of cells: one group establishes suspensor and the other raises embryo proper. Further development of protoderm and initiation of primordium at octant and globular stages occur (Dodeman et al. 1997). Auxin distribution causes formation of different tissues that eventually form an embryo and the expression of different embryogenesis genes takes place due to the interaction of auxins with cytokinins (Quiroz-Figueroa et al. 2002). Somatic embryogenesis of dicots shares same stages as zygotic embryogenesis and involves globular, heart, torpedo and cotyledonal stages of embryo formation (Winkelmann 2016), whereas monocots have globular, scutellar and coleoptile stages (Zhao et al. 2017). Cotyledonary stage gives rise to shoot mersitem and further explant growth continues (Yang and Zhang 2010).

\section{Auxin signalling pathway and its impact on cotton somatic embryogenesis}

Numerous studies have been performed to investigate somatic embryogenesis and its potential on genetic improvement of important crops. Gossypium hirsutum signaling pathways investigating somatic embryogenesis and connection of these pathways with phytohormones are the main topics to research (Zhou et al. 2016). Somatic embryogenesis consists of three stages, i.e., induction, establishing of meristematic core, and somatic embryo formation (Elhiti et al. 2013). These phases require specific factor interactions including changes in concentrations of endogenous hormones, external signals and interaction of different gene pathways. Molecular studies of somatic embryogenesis are difficult to perform because of challenging identification of somatic cells that will form embryos (Méndez-Hernández et al. 2019). Candidate genes involved in induction of somatic embryogenesis can be studied by transcriptomic research (Elhiti et al. 2013). Different metabolic pathways trigger somatic embryogenesis and there is a crucial role of auxin in formation of embryos (Nic-Can and LoyolaVargas 2016). Regeneration capacity of cells can be regulated by differential gene expression and total amount of genes that inactivated in somatic cells participating in the switching from somatic to embryogenic cells is higher than the number of genes that activated during somatic embryogenesis (Quiroz-Figueroa et al. 2002). Involvement of signaling pathway of auxin in modulation of particular Auxin response factors (ARF) transcripts is required during somatic embryogenesis of Arabidopsis (Wójcikowska and Gaj 2017). Transcription of approximately half of the 23 ARF genes occurs in somatic embryogenesis of Arabidopsis, where 6 of ARF genes are up-regulated and 5 genes are down-regulated. Several other genes such as putative Aux/IAA gene, EgIAA9 (Ooi et al. 2012) in cotton are involved in signal transduction pathway of auxin. Deep research of genes 
involved in somatic embryogenesis in cotton revealed 80 differentially-expressed genes connected to auxin metabolism (Yang et al. 2012). Regulation of specific genes is required to induce somatic embryogenesis that differentiate genetic program of the cell (Riechmann et al. 2000). Early and late stages of embryogenesis, gene expression in angiosperms and gymnosperms require investigation due to differences in development pathways (Trontin et al. 2017). It has been reported that there are similarities in gene expression patterns of angiosperms and gymnosperms during SE, particularly in presence of AaSERK1 from Araucaria angustifolia and homologs of SERK1 in angiosperms (Steiner et al. 2012). In another study between Arabidopsis thaliana and Oryza sativa, two auxin genes YUC10 and ARF17 have been found to be functionally conserved between monocots and dicots. Both genes are considered as 'imprinted genes' demonstrating evolutionary convergence for auxin biosynthesis in plants (Hsieh et al. 2011; Weinhofer et al. 2010).

Involvement of transcription factors is required for the signaling pathways and further changes during SE. Genomes of plants have large families $(6 \%$ 10\%) of transcription factors coding genes (Riechmann et al. 2000) and several of these families are shared in different species. The roles of auxin signaling pathway in gene expression are enormous including dedifferentiation and redifferentiation of cells through regulation, transduction and signalling pathway of auxin. Eighty-six genes involved in synthesis of auxin and its signalling pathway, transportation and metabolism were revealed (Yang et al. 2012). Moreover, these genes were involved in biosynthesis, metabolism of IAA, and related to transport of auxin, Aux/ IAA degradation, conjugate metabolism of IAA.

Exogenous application of auxins during somatic embryogenesis can enhance expression of TFs such as WUS, VP1 and BBM (Awasthi et al. 2017). Expression of several TFs such as WOUND INDUCED DEDIFFEREN TIATION1 (WIND1), a member of AP2/ERF family is specific to particular species. It was established that somatic embryogenesis in wounded tissues can express WIND1 before LEAFY COTYLEDON2 (LEC2) expression (Iwase et al. 2015). AP2/ERF family is highly expressed during SE and includes subfamilies that totally have 143 genes. LEC genes, members of AP2/ERF family, are involved in morphogenesis, maturation stages of embryogenesis. LEC1 is involved in photosynthesis, biogenesis of chloroplast (Pelletier et al. 2017). The first TFs revealed to induce SE in seedlings in the result of ectopic expression were LEC1 and LEC2 genes making collaboration with YUC genes (Stone et al. 2001). It was observed that LEC2 expression is auxin-dependent during SE, whereas Arabidopsis non-embryogenic callus had lower expression of LEC2 (Ledwon and Gaj 2009), supposing that LEC2 increase the amount of endogenous auxin during SE (Ayil-Gutiérrez et al. 2013). LEC2 in Theobroma cacao showed similar results to increase quantity of the gene in embryogenic calli (Zhang et al. 2014). LEC2 gene from Ricinus communis activated the expression of several transcription factors such as LEC1, L1L, FUS3, ABI3, and WRINKELED1 (WRI1) when ectopically expressed in A. thaliana (Kim et al. 2014).

BABY BOOM (BBM) family is encoded by APET ALA2/ETHYLENE RESPONSE FACTOR (AP2/ERF) and this transcription factor is DNA-binding type found in angiosperms, gymnosperms, mosses and algae, and it works as a network modulator in response to stresses (Kim et al. 2005). Domain of the AP2/ERF transcription factor binds to a DNA sequence GCC box that participates in response to ethylene (Ohme-Takagi and Shinshi 1995). Classification of AP2/ERF family is based on the total number of AP2 domains with subsequent division into subfamilies such as ERF, AP2, and RELATED TO ABI3/VP1 (RAV), Dehydration-responsive 427 element-binding (DREB) genes (Gutterson and Reuber 2004). Subfamily of RAV genes have additional DNA binding, B3 domain and based on this RAV genes are considered as the third class in AP2/ERF family (Kim et al. 2005). It was established that BBM switches its temporal and spatial expression patterns in Arabidopsis thaliana and Brassica napus during early embryogenesis (Kulinska-Lukaszek et al. 2012). Several studies show that the expression of BBM is found during root development and heart stage of an embryo (Galinha et al. 2007) and promotes development of embryos (Florez et al. 2015). Ectopic expression of BBM can switch from somatic to embryogenic growth in two species (Kulinska-Lukaszek et al. 2012) (Table 1). Regeneration capacity in Nicotiana tabacum was improved by BBM heterologous expression from Arabidopsis thaliana and Brassica napus (Srinivasan et al. 2007; Boutilier et al. 2002). High expression of BBM and LEC1 gene was observed in Capsicum annum during different stages of somatic embryogenesis (Irikova et al. 2012). BBM gene shows differential expression based on type of species and difference of embryogenic protocol used. In research of two types of Coffea genus, a BBM-like gene in C. Arabica expressed difference of two fold change in suspension of embryogenic cells compared with embryogenic callus (Silva et al. 2015), whereas BBM1 gene expression in C. canephora was found after somatic embryogenesis induction (Nic-Can et al. 2013). The study of BBM expression levels in T. cacao, a member of Malvaceae family, showed increased level of the gene during somatic embryogenesis in comparison with zygotic embryogenesis and ectopic expression of BBM gene in Theobroma cacao and Arabidopsis thaliana triggered phenotypes of SE without exogenous application of hormones. Although, subsequent inhibition of somatic embryos in T. cacao was observed in response to the overexpression of BBM gene (Florez et al. 2015), SE 
Table 1 The featured BBM and BBM-related genes in different plants and their functions related to growth and development

\begin{tabular}{|c|c|c|c|c|c|}
\hline Plant & Gene & Gene origin & Function & Rate & Reference \\
\hline \multicolumn{6}{|l|}{ Brassicaceae } \\
\hline $\begin{array}{l}\text { Arabidopsis } \\
\text { thaliana }\end{array}$ & AtBBM & Arabidopsis thaliana & $\begin{array}{l}\text { Somatic embryogenesis, cell } \\
\text { differentiation, cell growth, plant } \\
\text { regeneration }\end{array}$ & ${ }^{*}$ ng & $\begin{array}{l}\text { Boutilier et al. 2002; } \\
\text { Passarinho et al. 2008; } \\
\text { Kulinska-Lukaszek et al. 2012; } \\
\text { Lutz et al. } 2015\end{array}$ \\
\hline Brassica napus & BnBBM & Brassica napus & Somatic embryogenesis & ${ }^{*} \mathrm{ng}$ & Boutilier et al. 2002 \\
\hline \multicolumn{6}{|l|}{ Fabaceae } \\
\hline Glycine max & GmBBM1 & Glycine max & Somatic embryogenesis & $2 \% \sim 28 \%$ incr. & El Ouakfaoui et al. 2010 \\
\hline \multicolumn{6}{|l|}{ Malvaceae } \\
\hline $\begin{array}{l}\text { Theobroma } \\
\text { cacao }\end{array}$ & TcBBM & Theobroma cacao & $\begin{array}{l}\text { Somatic embryogenesis (faster), } \\
\text { biomarker for developmental process }\end{array}$ & 5.5-fold incr. & Florez et al. 2015 \\
\hline \multicolumn{6}{|l|}{ Musaceae } \\
\hline $\begin{array}{l}\text { Musa } \\
\text { acuminata }\end{array}$ & $\begin{array}{l}\text { MaBBM1, } \\
\text { MaBBM2 }\end{array}$ & Musa acuminata & Somatic embryogenesis & ${ }^{*} \mathrm{ng}$ & Awasthi et al. 2017 \\
\hline \multicolumn{6}{|l|}{ Poaceae } \\
\hline Oryza sativa & OsBBM1 & Oryza sativa & Haploid induction, parthenogenesis & $5-29 \%$ incr. & Khanday et al. 2019 \\
\hline Oryza sativa & $\begin{array}{l}\text { PSASGR- } \\
\text { BBML }\end{array}$ & $\begin{array}{l}\text { Pennisetum } \\
\text { squamulatum }\end{array}$ & Haploid induction & $25-89 \%$ incr. & Conner et al. 2017 \\
\hline Oryza sativa & ZmBBM & Zea mays & Transformation efficiency & 15-fold incr. & Lowe et al. 2016 \\
\hline $\begin{array}{l}\text { Pennisetum } \\
\text { glaucum }\end{array}$ & $\begin{array}{l}\text { PSASGR- } \\
\text { BBML }\end{array}$ & $\begin{array}{l}\text { Pennisetum } \\
\text { squamulatum }\end{array}$ & Apomixis & $35-36 \%$ incr. & Conner et al. 2015 \\
\hline $\begin{array}{l}\text { Saccharum } \\
\text { officinarum }\end{array}$ & ZmBBM & Zea mays & Transformation efficiency & 130-440-fold incr. & Lowe et al. 2016 \\
\hline $\begin{array}{l}\text { Sorghum } \\
\text { bicolor }\end{array}$ & ZmBBM & Zea mays & Transformation efficiency & 9-fold incr. & $\begin{array}{l}\text { Lowe et al. 2016; } \\
\text { Mookan et al. } 2017\end{array}$ \\
\hline Zea mays & $\begin{array}{l}\text { PSASGR- } \\
\text { BBML }\end{array}$ & $\begin{array}{l}\text { Pennisetum } \\
\text { squamulatum }\end{array}$ & Haploid induction & $47-80 \%$ incr. & Conner et al. 2017 \\
\hline Zea mays & ZmBBM2 & Zea mays & $\begin{array}{l}\text { Bigger callus induction, proliferation, } \\
\text { transformation efficiency (TE) }\end{array}$ & $\begin{array}{l}\text { 3.5 6.6-fold incr. } \\
\text { (20-21\% TE) }\end{array}$ & Du et al. 2019 \\
\hline Zea mays & $\begin{array}{l}\text { ZmBBM, } \\
\text { ZmWUS2 }\end{array}$ & Zea mays & Transformation efficiency & $4-14 \%$ incr. & Masters et al. 2020 \\
\hline $\begin{array}{l}\text { L. kaempferix } \\
\text { L. olgensis }\end{array}$ & LkBBM2 & L. kaempferi $\times$ L. olgensis & Number of adventitious root formation & $100 \%$ incr. & Li et al. 2014 \\
\hline \multicolumn{6}{|l|}{ Pteridaceae } \\
\hline $\begin{array}{l}\text { Ceratopteris } \\
\text { richardii }\end{array}$ & BnBBM & Brassica napus & Promote apogamy & $44.8 \%$ incr. & Bui et al. 2017 \\
\hline \multicolumn{6}{|l|}{ Rosaceae } \\
\hline Rosa canina & $\begin{array}{l}\text { RcBBM1, } \\
\text { RcBBM2 }\end{array}$ & Rosa canina & Shoot regeneration & $20 \%$ incr. & Yang et al. 2014 \\
\hline \multicolumn{6}{|l|}{ Rubiaceae } \\
\hline Coffea arabica & CaBBM & Coffea arabica & Developmental process & ${ }^{*}$ ng & Silva et al. 2015 \\
\hline \multicolumn{6}{|l|}{ Salicaceae } \\
\hline $\begin{array}{l}\text { Populus } \\
\text { tomentosa }\end{array}$ & PtBBM & Populus tomentosa & $\begin{array}{l}\text { Somatic embryogenesis (SE), } \\
\text { transformation efficiency }\end{array}$ & $\begin{array}{l}39 \% \text { incr. (SE), } \\
29 \% \text { incr. (TE) }\end{array}$ & Deng et al. 2009 \\
\hline \multicolumn{6}{|l|}{ Solanaceae } \\
\hline $\begin{array}{l}\text { Capsicum } \\
\text { annuum }\end{array}$ & BnBBM & Brassica napus & Transformation efficiency & $0.6-1.1 \%$ incr. & Heidmann et al. 2011 \\
\hline $\begin{array}{l}\text { Nicotiana } \\
\text { tabacum }\end{array}$ & $\begin{array}{l}\text { BnBBM, } \\
\text { AtBBM }\end{array}$ & $\begin{array}{l}\text { Brassica napus, } \\
\text { Arabidopsis thaliana }\end{array}$ & Promote regeneration ability & ${ }^{*} \mathrm{ng}$ & Srinivasan et al. 2007 \\
\hline
\end{tabular}

${ }^{*}$ ng: the degree of effect was not given in literature, incr. increase 
was induced in Populus tomentosa in response to BBM overexpression (Deng et al. 2009).

$\mathrm{BBM}$ is one of the major regulators of cell totipotency that enhances regeneration capacity and considered as a vital factor for plant embryogenesis as the mechanism described in Fig. 1 (Irikova et al. 2012). BBM is upstream of several genes, such as LEC1/LEC2, ABI3 and FUS3 network that trigger SE together. BBM is dose and context dependent mechanism when expressed ectopically and transcription of several embryo identity genes are regulated by BBM gene (Horstman et al. 2017). LEC1 encodes subunit B of a nuclear factor Y protein (NFYB), and the B3 domain protein LEC2 (Lotan et al. 1998; Stone et al. 2001).

B3 domain proteins FUS3 and ABI3 and LEC1/LEC2 together with LEC1-LIKE (L1L) refer to LAFL network (for LEC1/L1L, ABI3, FUS3, and LEC2) (Jia et al. 2014). BBM triggered SE is quantitatively regulated by LEC2 and ABI3, whereas LEC1 and FUS3 are also important for this process (Horstman et al. 2017; Wójcik et al. 2020; Wójcikowska et al. 2020; Jha et al. 2020; Kumar and Jha 2020) (Fig. 2). LAFL gene expression can be regulated by another BBM-like protein, PLETHORA2 and in early embryogenesis LAFL network regulate embryo identity and embryo maturation with accumulation of storage products in later processes (Jia et al. 2013). It was established that several embryo traits can be conferred by FUS3 and ABI3 although they do not trigger
SE (Parcy et al. 1994; Parcy and Giraudat 1997; Gazzarrini et al. 2004). Seed maturation expression, signaling response of auxin and biosynthesis genes are directly regulated by LEC1 and LEC2 (Lotan et al. 1998; Braybrook et al. 2006), which supposedly induce totipotent state (Braybrook and Harada 2008). Ectopic expression of LEC2 can directly activate AGAMOUS-LIKE15 (AGL15) gene, member of MADS box transcription factor, which enhances SE in immature zygotic embryos (Harding et al. 2003; Braybrook et al. 2006) and activates IAA30 (Indole-3-Acetic Acid Inducible 30) (Braybrook et al. 2006; Zheng et al. 2009). LEC2 through BBM induction also activates IAA30 (Braybrook et al. 2006; Zheng et al. 2009). The association level of AHL15/ AHL20 with IAA30 was not determined yet. Gene expression of LAFL network was modulated by transcription factors such as PICKLE (PKL), chromatin remodeler and VIVIPAROUS1/ABI3-LIKE (VAL)/ HIGH-LEVEL EXPRESSION OF SUGAR-INDUCIBLE GENE (HSI) which contain B3 domain.

LAFL network can have increased gene expression when PKL and VAL genes are mutated (Ogas et al. 1999; Rider Jr et al. 2003; Henderson et al. 2004; Suzuki et al. 2007). BBM was revealed to trigger cell totipotency by transcriptionally activating the network of LAFL genes in germinating seeds. Signaling pathway of BBM gene was studied by analysis of DNA-binding sites during somatic embryogenesis (Horstman et al. 2015).

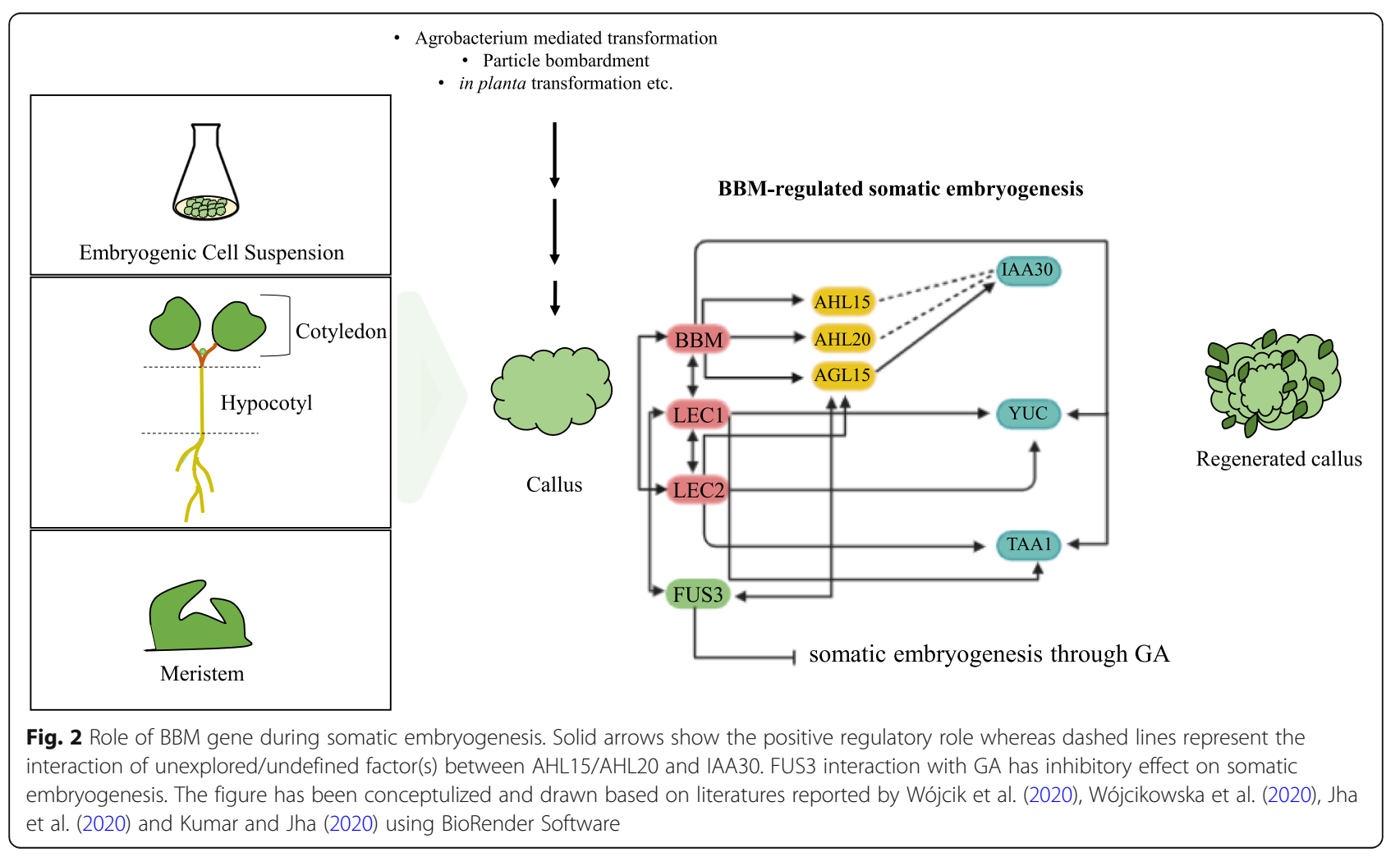


BBM triggers somatic embryogenesis and this is a well known phenomenon today, however, the pathway behind this needs to be explored in detail. The present lterature is evident of the role of BBM in inducing major auxin biosynthesis and transport genes involved in somatic embryogenesis (Heidmann et al. 2011). A plenty of plants particularly recalcitrant in tissue culture have already shown high rates of somatic embryogenesis such as soybean as a striking example (El Ouakfaoui et al. 2010) and this response can be promising for other recalcitrant plants including cotton. Besides that, the overexpression of BBM in Theobroma cacao (belonging to Malvaceae family, same as cotton) resulted in 5.5-fold increased somatic embryogenesis that is encourging for the cotton researchers as a similar pattern of increased somatic embryogenesis can be observed in cotton as well (Florez et al. 2015). Several recent studies have already revealed possible associations between somatic embryogenesis related genes (ABI3, AGL15, FUS3, LEC1, LEC2, WUS, BBM) and auxin genes (ARF, AuxIAA, GH3, SAUR) in cotton (Sun et al. 2019; Wen et al. 2020). Cotton transcriptomic data revealed that highly regenerative cotton cultivar - Jin668 has highly upregulated expression levels of BBM (Gohir.A08G227000), FUS3 (Gohir.A07G230400) and AGL15 genes in embryogenic calli (Wen et al. 2020) in comparison with WUS and LEC1 (Gohir.A13G132600 and Gohir.A08G025100). Same study even pointed out that these genes must synchronously function with auxin pathway to trigger

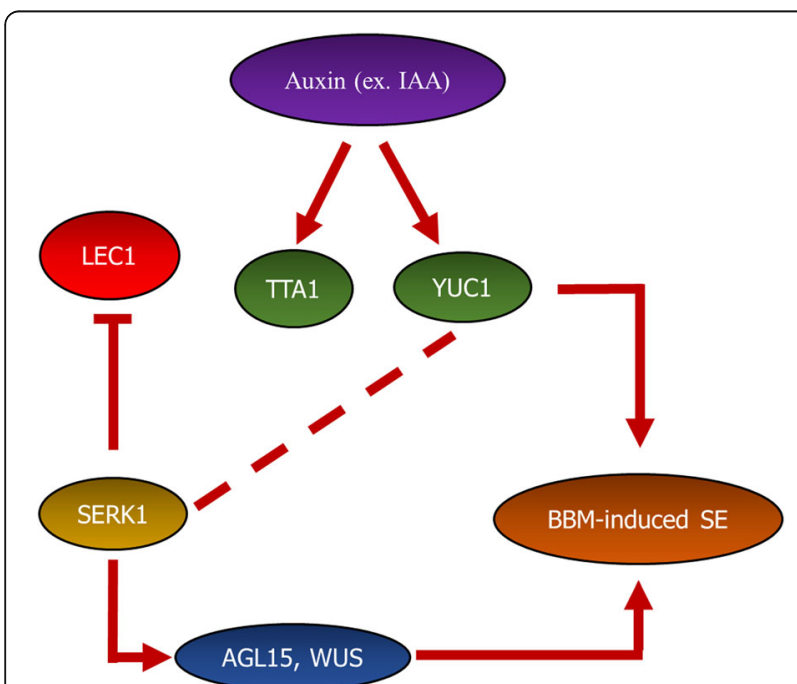

Fig. 3 Auxin signalling and its possible involvement in BBM induced somatic embryogenesis. Solid arrows show the positive regulatory role whereas the dashed line represents the regulatory role between SERK1 and BBM that has not been investigated yet. SERK1 had inhibitory effect on LEC1, LEC2 and FUS3. SE: Somatic

embryogenesis. The figure has been conceptulized and drawn using scientific literatures by Ayil-Gutiérrez et al. (2013) and Pérez-Pascual et al. (2018) somatic embryogenesis in cotton (Wen et al. 2020). Furthermore, Sun et al. (2019) reported the co-expression of BBM gene with other auxin early response genes (ARF, AuxIAA, GH3 and SAUR) involved in somatic embryogenesis genes except WUS.

The increase in endogenous IAA and its conjugation led to the enhance expression level of genes encoding for tryptophan aminotransferase of Arabidopsis (CcTAA1) and YUCCA, CcYUC1 (enzyme flavin monooxygenase) that are involved in somatic embryogenesis of Coffea canephora (Ayil-Gutiérrez et al. 2013) as depicted in Fig. 3. SERK1 (somatic embryogenesis receptor kinase 1) directly activates BBM and indirectly affects BBM pathway by intermittent activation of AGL15 and WUS genes (Pérez-Pascual et al. 2018). LEC1, however, is downregulated with increased SERK1 expression levels in Coffea canephora (Pérez-Pascual et al. 2018) and this interaction should be explored with further studies for all plants. Moreover, key auxin pathway genes such as YUC together with BBM can become new efficient tools against low transfromation efficiency and recalcitrance of many plants species.

\section{Cotton somatic cell de-differentiation and re- differentiation and their transcriptional regulation}

Transcriptional modulation of numerous genes is reflected by different changes occuring during somatic embryogenesis (Thibaud-Nissen 2003; Sung and Okimoto 1983; Zhu et al. 2008) and activation or downregulation of these genes during growth and development of embryos have been studied by molecular methods (Hecht et al. 2001; Hu et al. 2011). However, regulation and transcriptional changes need to be investigated and molecular functions and networks can be studied by genome-wide expression analyses. Microarrays (Zhu et al. 2008; Wu et al. 2009; Zeng et al. 2006), suppression subtractive hybridization (SSH), polymorphisms analysis (Leng et al. 2007) have been provided to investigate transcriptome dynamics of cotton somatic embryogenesis and dedifferentitation of cells, but there is a need for further complete studies of cotton SE. Technologies of next-generation sequencing are significant in genome expression analyses such as RNA sequencing (Zheng et al. 2010), Illumina (Wang et al. 2010) and ABI SOLiD (Tang et al. 2009).

Somatic cells of plants have necessary genetic information for forming functional organism and SE involve termination of several genes of somatic tissue, further replaced by embryogenic programmne of gene expression (Yang and Zhang 2010). Primary explant has definite restricted responsive cells for initiation of embryogenesis that undergo dedifferentiation due to necessity of switching off the developmental code of somatic 
cells and being replaced by new pathway (Yang and Zhang 2010; Fehér et al. 2003).

Somatic embryogenesis of cotton involves complex processes including restricted cellular events, dedifferentiation phases, reactivation cycle of cells and accession of embryogenic capacity (Yang et al. 2012). Transcription factors regulate certain embryogenesis stages (Jenik et al. 2007) or the whole pathway of development (Park and Harada 2008). In the study provided by Yang et al. (2012), 466 TF mRNAs were discovered to be differentially expressed during SE and several TF families such as MYB, bHLH, b-ZIP, B3 and Zinc finger were linked to processes of differentiation, patterning and maturation while GRAS, YABBY, NAC were linked with maintenance of meristem. Several TFs were associated with auxin signalling pathway such as Aux/IAA, ARF and ethylene mediated AP2/ ERF. Several genes, such as LEC2, FUS3 and ABI3, were discovered to have a regulatory role in embryogenesis. Six of B3 domain TF homologues were found to have different expression patterns: one was up-regulated and two were down-regulated. The study of Yang et al. (2012) showed differentiallyexpressed 26 AP2/ERF genes during cotton somatic embryogenesis.

Significance of plant hormones during somatic embryogenesis and their impact on molecular pathways are widely investigated (Fehér et al. 2003; Jiménez 2005). Hormonal regulation during somatic embryogenesis can be evaluated by adding hormones to culture medium and futher endogenous hormone measurement of plant tissues in different stages of growth (Jiménez and Bangerth 2001). The role of auxin is very critical including participation in cell division, induction of somatic embryogenesis. Modulation occurs due to auxin gradients throughout somatic embryogenesis necessary for dedifferentiation and division of existing differentiated cells (Jiménez 2005). Although, plants produce native auxin IAA, there is a need of exogenous auxin application for in vitro cells. For instanse, endogenous IAA concentration increases in response to exogenous auxin application in carrot cells. Therefore, induction phase of SE requires both hormone type accumulation and increased levels of exogenous auxin (Jiménez et al. 2001; Michalczuk et al. 1992). Some studies on SE provided evaluation of EC and NEC cultures (Zeng et al. 2007; Jiménez 2005), some gave information about concentrations of endogenous auxins, dedifferentiation of cells in response to hormones and totally-formed embryogenic cells.

\section{Transformation efficiency in cotton}

Developing new varieties in cotton with improved breeding traits and tolerance to biotic/abiotic stress using conventional breeding approaches has limited applicability and the reason is principally arising from the restriction in reaching proper germplasm with desired traits and difficulty in introgression of these traits into selected cultivar (Hussain et al. 2005). Cotton is a recalcitrant plant which demands lengthy and tedious handling process to be maintained in tissue culture (Khan et al. 2010; Chakravarthy et al. 2014). Biotechnological advances particularly regarding transformation studies and those efforts to increase transformation success in cotton are therefore very valuable to exploit the potential of transgenic cotton (Hussain et al. 2005). For instance, $90 \%$ of cotton produced in the USA today is made up of insecticide and herbicide resistant transgenic cotton and this has reduced the use of insecticides by almost half in USA and in Australia as well (Rajasekaran 2019; Benedict and Altman 2001). Although significant achievements have been made in this field, the studies for other breeding traits such as fiber quality, yield, earliness are not at desired level yet (Sattar et al. 2019). Accordingly it is very critical to improve and develop reproducible transformation protocols for cotton.

The first successful transformation study in cotton was reported in two separate studies which were able to develop transgenic cotton with Agrobacterium-mediated transformation of cotyledonary explants. They used Coker 210 and Coker 312 G. hirsutum genotypes, respectively, and later found that these Coker-derived cultivars had high somatic embryogenesis capacity but very low transformation efficiency was found (Firoozabady et al. 1987; Umbeck et al. 1987). These studies were followed by further examples of Agrobacterium-mediated transformation in cotton (Lyon et al. 1993; Thomas et al. 1995). Agrobacterium-mediated transformation is still the most favourite approach for cotton transformation especially for being simple and easy in methodology and having low number of copies but it is a lengthy process which takes about 10 12 months to regenerate after transformation (Jin et al. 2005). Ongoing studies are particularly focusing on reducing the long and laborious process, testing non-Coker related cultivars' responses to regeneration, adapting different explant types and selection media to obtain optimal, reproducible and reliable conditions for Agrobacteriummediated transformation in cotton. Early examples of transformation were dependent on cotyledonary and hypocotyl explants from which regeneration took almost 1 year. However, studies have shown that time can be shortened by using embryogenic callus and pistil drip (Hussain et al. 2005; Jin et al. 2005). Agrobacterium-mediated transformation of embryogenic callus had about $15 \%$ transformation success in cotton providing an efficient protocol for transformation (Jin et al. 2005) and another research supported that culturing period can be minimized with embryogenic callus (Leelavathi et al. 2004). However its main drawback is being genotype- 
dependent which limits its application. Embryogenic calli can be also cryopreserved favouring a time flexible transformation opportunity and making it more practical compared with other explant types (Leelavathi et al. 2004). Transformation efficiency was calculated as $60-70 \%$ in explants transformed with Agrobacterium using shoot tip and same protocol was also repeated in a study where transformation success rate was still quite low, $0.2 \%$ in local Indian cotton cultivars (Satyavathi et al. 2002; Katageri et al. 2007). Other relevant studies had about 5-10\% transformation success using shoot tips (Finer and McMullen 1990; Gould and Magallanes-Cedeno 1998; Majeed et al. 2000; Bakhsh et al. 2012, 2016) claiming that transformation efficiency using shoot tips still demands standardization. The effects of different explants such as embryo and pistil drip on Agrobacterium-mediated transformation were investigated in different studies and it has been reported that pretreatment of embryos with potassium chloride promoted transformation efficiency by $1.10 \%$, while pistil drip method gave genotype independent results with $0.55 \%$ transformation success yet, and the rate of chimeric plant formation after transformation was high in pistil drop method (Barpete et al. 2016; Zhang and Chen 2012).

Agrobacterium-mediated transformation is still the main method used for cotton transformation but it is time consuming (Sunilkumar and Rathore 2001; Khabbazi et al. 2018). An alternative transformation method, particle bombardment, was known to have high transformation efficiency. This approach can generate transgenic cotton in short periods ( 3 months), almost saving 7 9 months for transformation (Chlan et al. 1995). First studies about particle bombardment in cotton were conducted by Finer and McMullen (1990). Rajasekaran et al. (2000) found an average transient transformation efficiency, 4\%, in cotton. Embryogenic cell suspensions are the primary explant source for particle bombardment and meristematic tissues are making up the second most explant type in cotton (McCabe and Martinell 1993; Chlan et al. 1995; Rajasekaran et al. 2000). Transgenic plants generated by particle bombardment tend to have high copy number of trans gene unlike Agrobacteriummediated transformation (Sunilkumar and Rathore 2001). This method, even if requires less time for transformation, may have difficulty in inducing embryogenic callus formation from different genotypes which is already known to be restricted to some certain genotypes such as Coker varieties. Other recalcitrant cultivars such as Acala, Pima may need time to produce embryogenic cell suspension in the beginning but after having a stock of embryogenic cell suspension, transformation may become easier and shorter (Rajasekaran 2019).

Considering all advantages and disadvantages of transformation efficiency in cotton mentioned in this section, cotton still needs a reliable and genotype independent approach for transformation. BBM gene and its interaction with other transcription factors such as WUS2 have known to promote transformation efficiency in both monocots (Lowe et al. 2016; Du et al. 2019) and dicots (Heidmann et al. 2011). Only limited Agrobacterium strains are available for monocot transformation and phenolics production as a result of wounding complicates cereal transformation (Sood et al. 2011; Hoffman 2016). Overexpression of BBM and WUS2 genes from maize was shown to increase transformation efficiency in rice and in sorghum by 15 fold and 9 fold, respectively, and with a fantastic increase in sugarcane by 130 440 fold, unlike $2 \%$ transformation rate in control sugarcane plants using Agrobacterium-mediated transformation as given in Table 1 (Lowe et al. 2016). They also included drought inducible promoter in transgenic cassette which may help to excise marker gene with CreLoxP system later (Lowe et al. 2016). A recent study also claimed that overexpression of $Z m B B M 2$ gene was capable of increasing transformation rate in two different maize cultivars, CAL and Zong31 at different rates, from $6 \%$ (control) to $21 \%$ (overexpressed) and from 3\% (control) to $20 \%$ (overexpression), respectively ( $\mathrm{Du}$ et al. 2019). These two maize BBM genes, $Z m B B M$ and $Z m B B M 2$, had $43 \%$ similarity and they both succeed in increasing transformation capacity of different monocots. Studies with BBM gene in dicots regarding transformation efficiency are very less compared with monocots but there is one successful example conducted in two different sweet pepper cultivars. They fused BBM gene from Brassica napus with glucocorticoid receptor to help sequestering excess BBM in the presence of dexamethason and even the rates obtained, are far below the success in monocots, an increase in transformation percentage of about $0.6-1 \%$ was reported (Heidmann et al. 2011). Similar approach can be applied in cotton to increase transformation success rate.

\section{Conclusion and future prospects}

There is a dire need to introduce major transformations in global food system to feed 800 million chronically hungry and 2 billion micro-nutrient deficient people. Plant breeding has done wonders in increasing crop yield in last 100 years (Evenson and Gollin 2003). Even then hunger is still widespread in many countries. The recent advances in functional genomics are game changing tools for plant breeders to boost agricultural productivity and to feed increasing population in the long run. Cotton is an important crop for world economy as it is essentially produced for its fibre that is universally used as textile raw material (Bakhsh et al. 2015). Cotton by-products generate sustainable income oppurtunities for farming communities. More than 100 countries grow 
cotton while 150 countries are involved in its import and export. The livelihood of millions is associated with cotton crop from field to fabric. Cotton offers several challenges to plant breeders from its cultivation to harvesting and is under threat of insect pest, weeds and diseases since its emergence from soil. The genetic improvements in cotton have been made against insect pests by incorporating gene(s) from Bacillus thuringiensis whereas resistance against herbicide has been achieved by transfering cp4-esps sythase gene from Agrpbacterim tumefaciens (ISAAA 2018). However, protocol for in vitro regeneration via tissue culture is highly genotype dependent, laborious and time consuming. A reproducible, time-saving and genotype-independent protocol can increase the pace of genetic improvements in cotton. The understanding of genetic control of somatic embryogenesis revealed that certain transcription factors are specially induced and expressed during somatic embryogenesis. BBM transcription factors regulate cell totipotency and are involved in cell proliferation, growth and development. Sun et al. (2018) compared transcriptomes of two cotton cultivars and found 46 transcripts involving in conversion of non-embryogenic calli to embryogeneic calli. Likewise, heterologous expression of BBM transcription factor in tobacco and rapeseed increased its regeneration capacity. Other studies in Arabidopsis thaliana, Glycine max and Brassica napus, Theobroma cacao etc. also establish the role of these transcription factors in inducing embryogenesis. Therefore, we believe that the ectopic or overexpression of BBM gene(s) in a cotton genotype can increase its regeneration potential during tissue culture phase. It would reveal increased somatic embryo induction, transfromation efficiency and overall growth and development. Once part of genome, the same genotype further can be used to incorporate any gene(s) encoding economic important traits in it and can serve as germplasm to breed other cultivars as well. Hence, the problem of cotton regeneration and transformation can be better understood by integrating one or more copies of BBM gene(s) in cotton genotypes.

\section{Acknowledgements}

Authors acknowledge the valuable research work of fellow researchers who have contibuted to the understanding the role of BABY BOOM transcription factors in somatic enbryogenesis. We would like to apologize those fellows whose work could not be cited in article although we have tried our best to include all relevant studies.

\section{Authors' contributions}

Yavuz $C$ and Tillaboeva $S$ had through literature survey and wrote intial draft of manuscript. Bakhsh A conceived the idea, worked on final drafting and presented manuscript in its current form. The authors' read and approved the final manuscript.

\section{Funding}

No any funds were received from any agency for this study.

\section{Availability of data and materials}

The data used in manuscript has previously published in form of research and review article.

Ethics approval and consent to participate

Not applicable.

\section{Consent for publication}

Not applicable.

\section{Competing interests}

The authors declare that they have no competing interests.

Received: 30 April 2020 Accepted: 11 October 2020

Published online: 03 November 2020

\section{References}

Abid G, Jaquemin JM, Sassi K, et al. Gene expression and genetic analysis during higher plants embryogenesis. Biotechnol Agron Soc. 2010;14(4):667-80.

Awasthi P, Sharma V, Kaur N, et al. Genome-wide analysis of transcription factors during somatic embryogenesis in banana (Musa spp.) cv. Grand naine. PLoS One. 2017;12(8). https://doi.org/10.1371/journal.pone.0182242.

Ayil-Gutiérrez BA, Galaz-Ávalos RM, Peña-Cabrera E, et al. Dynamics of the concentration of IAA and some of its conjugates during the induction of somatic embryogenesis in Coffea canephora. Plant Signal Behav. 2013;8: e26998. https://doi.org/10.4161/psb.26998.

Bakhsh A, Anayol E, Khabbazi SD, et al. Development of insect-resistant cotton lines with targeted expression of insecticidal gene. Arch Biol Sci. 2016;68(4): 773-80. https://doi.org/10.2298/ABS151012063B.

Bakhsh A, Khabbazi SD, Baloch FS, et al. Insect resistant transgenic crops: retrospects and challenges. Turk J Agric For. 2015;39:531-48. https://doi.org/ 10.3906/tar-1408-69.

Bakhsh A, Siddique S, Husnain T. A molecular approach to combat spatiotemporal variation in insecticidal gene (Cry1 Ac) expression in cotton. Euphytica. 2012;183(1):65-74. https://doi.org/10.1007/s10681-011-0497-8.

Barpete S, Bakhsh A, Anayol E, et al. Inducing osmotic stress leads to better genetic transformation efficiency in cotton (Gossypium hirsutum L.). Turk J Biol. 2016;40:826-36. https://doi.org/10.3906/biy-1509-16.

Benedict J, Altman D. Commercialization of transgenic cotton expressing insecticidal crystal protein. In: Jenkins L, Saha S, editors. Genetic improvement of cotton: emerging technologies. Enfield, New Hampshire, USA: Science Publishers; 2001. p. 137-201.

Boutilier K, Offringa R, Sharma VK, et al. Ectopic expression of BABY BOOM triggers a conversion from vegetative to embryonic growth. Plant Cell. 2002; 14(8):1737-49. https://doi.org/10.1105/tpc.001941.

Boyer JS. Plant productivity and environment. Science. 1982;218(4571):443-8.

Braybrook SA, Harada JJ. LECs go crazy in embryo development. Trends Plant Sci. 2008;13(12):624-30. https://doi.org/10.1016/j.tplants.2008.09.008.

Braybrook SA, Stone SL, Park S, et al. Genes directly regulated by LEAFY COTYLEDON2 provide insight into the control of embryo maturation and somatic embryogenesis. PNAS. 2006;103(9):3468-73. https:/doi.org/10.1073/pnas.0511331103.

Bui LT, Pandzic D, Youngstro C, et al. A fern AINTEGUMENTA gene mirrors BABY BOOM in promoting apogamy in Ceratopteris richardii. Plant J. 2017;90(1): 122-32. https://doi.org/10.1111/tpj.13479.

Chakravarthy VSK, Reddy TP, Reddy VD, et al. Current status of genetic engineering in cotton (Gossypium hirsutum L.): an assessment. Crit Rev Biotechnol. 2014;34(2):144-60. https://doi.org/10.3109/07388551.2012.743502.

Chlan CA, Lin J, Cary JW, et al. A procedure for biolistic transformation and regeneration of transgenic cotton from meristematic tissue. Plant Mol Biol Rep. 1995;13(1):31-7. https://doi.org/10.1007/BF02668391.

Conner JA, Mookkan M, Huo H, et al. A parthenogenesis gene of apomict origin elicits embryo formation from unfertilized eggs in a sexual plant. PNAS. 2015; 112(36):11205-10. https://doi.org/10.1073/pnas.1505856112.

Conner JA, Podio M, Ozias-Akins P. Haploid embryo production in rice and maize induced by PSASGR-BBML transgenes. Plant Reprod. 2017;30(1):41-52. https:// doi.org/10.1007/s00497-017-0298-x.

Deng W, Luo KM, Li ZG, et al. A novel method for induction of plant regeneration via somatic embryogenesis. Plant Sci. 2009;177:43-8. https://doi. org/10.1023/A:1022800512708.

Dodeman VL, Ducreux G, Kreis M. Zygotic embryogenesis versus somatic embryogenesis. J Exp Bot. 1997;48:1493-509. https://doi.org/10.1093/jxb/48.8.1493. 
Du X, Fang T, Liu Y, et al. Transcriptome profiling predicts new genes to promote maize callus formation and transformation. Front Plant Sci. 2019:10:1633. https://doi.org/10.3389/fpls.2019.01633.

Duncan DR. Cotton transformation. In: Zehr UB, editor. Cotton: biotechnology advances. Berlin: Springer; 2010. p. 65-77.

El Ouakfaoui S, Schnell J, Abdeen A, et al. Control of somatic embryogenesis and embryo development by AP2 transcription factors. Plant Mol Biol. 2010;74: 313-26. https://doi.org/10.1007/s11103-010-9674-8.

Elhiti M, Stasolla C, Wang A. Molecular regulation of plant somatic embryogenesis. In Vitro Cell Dev Biol Plant. 2013;49:631-42. https://doi.org/ 10.1007/s11103-010-9674-8

Evenson RE, Gollin D. Assessing the impact of the green revolution, 1960 to 2000. Science. 2003;300:758-62. https://doi.org/10.1126/science.1078710.

Fehér A, Pasternak TP, Dudits D. Transition of somatic plant cells to an embryogenic state. Plant Cell Tissue Organ Cult. 2003;74:201-28. https://doi. org/10.1023/A:1024033216561.

Finer J, McMullen M. Transformation of cotton (Gossypium hirsutum L.) via particle bombardment. Plant Cell Rep. 1990;8:586-9. https://doi.org/10.1007/ BF00270059.

Firoozabady E, DeBoer DL, Merlo DJ, et al. Transformation of cotton (Gossypium hirsutum L.) by Agrobacterium tumefaciens and regeneration of transgenic plants. Plant Mol Biol. 1987;10:105-16. https://doi.org/10.1007/BF00016148.

Florez SL, Erwin RL, Maximova SN, et al. Enhanced somatic embryogenesis in Theobroma cacao using the homologous BABY BOOM transcription factor. BMC Plant Biol. 2015;15:121. https://doi.org/10.1186/s12870-015-0479-4.

Galinha C, Hofhuis H, Luijten M, et al. PLETHORA proteins as dose-dependent master regulators of Arabidopsis root development. Nature. 2007;449:1053-7. https://doi.org/10.1038/nature06206

Garcês HMP, Sinha N. The 'mother of thousands' (Kalanchoë daigremontiana): a plant model for asexual reproduction and CAM studies. Cold Spring Harb Protoc. 2009;10. https://doi.org/10.1101/pdb.emo133 .

Gazzarrini S, Tsuchiya Y, Lumba S, et al. The transcription factor FUSCA3 controls developmental timing in Arabidopsis through the hormones gibberellin and abscisic acid. Dev Cell. 2004;7(3):373-85. https://doi.org/10.1016/j.devcel. 2004.06.017

Goldberg RB, De Paiva G, Yadegari R. Plant embryogenesis: zygote to seed. Science. 1994;266:605-14. https://doi.org/10.1126/science.266.5185.605.

Gould J, Magallanes-Cedeno M. Adaptation of cotton shoot apex culture to Agrobacterium-mediated transformation. Plant Mol Biol Repor. 1998;16:1-10. https://doi.org/10.1023/A:1007438104369.

Gutterson N, Reuber TL. Regulation of disease resistance pathways by AP2/ERF transcription factors. Curr Opin Plant Biol. 2004;7:465-71. https://doi.org/10. 1016/j.pbi.2004.04.007

Harding EW, Tang W, Nichols KW, et al. Expression and maintenance of embryogenic potential is enhanced through constitutive expression of AGAMOUS-like 15. Plant Physiol. 2003;133:653-63. https://doi.org/10.1104/pp.103.023499.

Hecht V, Vielle-Calzada JP, Hartog MV, et al. The Arabidopsis Somatic Embryogenesis Receptor Kinase 1 gene is expressed in developing ovules and embryos and enhances embryogenic competence in culture. Plant Physiol. 2001;127:803-16. https://doi.org/10.1104/pp.010324

Heidmann I, de Lange B, Lambalk J, et al. Efficient sweet pepper transformation mediated by the BABY BOOM transcription factor. Plant Cell Rep. 2011;30(6): 1107-15. https://doi.org/10.1007/s00299-011-1018-x.

Henderson JT, Li HC, Rider SD, et al. PICKLE acts throughout the plant to repress expression of embryonic traits and may play a role in gibberellin-dependent responses. Plant Physiol. 2004;134:995-1005. https://doi.org/10.1104/pp.103.030148.

Hoffman NR. A breakthrough in monocot transformation methods. Plant Cell. 2016;28:1989. https://doi.org/10.1105/tpc.16.00696.

Horstman A, Fukuoka H, Muino JM. AlL and HDG proteins act antagonistically to control cell proliferation. Dev. 2015;142:454-64. https://doi.org/10.1242/dev.117168.

Horstman A, Li M, Heidmann I, et al. The BABY BOOM transcription factor activates the LEC1-ABI3-FUS3- LEC2 network to induce somatic embryogenesis. Plant Physiol. 2017;175:848-57. https://doi.org/10.1104/pp. 17.00232 .

Hsieh TF, Shin J, Uzawa R, et al. Regulation of imprinted gene expression in Arabidopsis endosperm. PNAS. 2011;108:1755-62. https://doi.org/10.1073/ pnas.1019273108.

Hu LS, Yang XY, Yuan DJ, et al. GhHmgB3 deficiency deregulates proliferation and differentiation of cells during somatic embryogenesis in cotton. Plant Biotechnol J. 2011;9:1038-48. https://doi.org/10.1111/j.14677652.2011.00617.x

Hussain SS, Husnain T, Riazuddin S. In-ovule embryo culture: a novel method of cotton transformation. Pak J Biol Sci. 2005:8(2):297-301. https://doi.org/10. 3923/pjbs.2005.297.301.

Irikova T, Grozeva S, Denev I. Identification of BABY BOOM and LEAFY COTYLEDON genes in sweet pepper (Capsicum annuum L.) genome by their partial gene sequences. Plant Growth Regul. 2012;67:191-8. https://doi.org/ 10.1007/s10725-012-9676-4.

ISAAA. Global Status of Commercialized Biotech/GM Crops in 2018. ISAAA Brief 54. Ithaca: ISAAA; 2018.

Iwase A, Mita K, Nonaka S, et al. WIND1-based acquisition of regeneration competency in Arabidopsis and rapeseed. J Plant Res. 2015;128:389-97. https://doi.org/10.1007/s10265-015-0714-y.

Jabran K, UI-Allah S, Chauhan BS, et al. An Introduction to global production trends and uses, history and evolution, and genetic and biotechnological improvements in cotton. In: Jabran K, Chauhan BS, editors. Cotton production. 2019. p.1-22. Wiley Online Library. https://doi.org/10.1002/ 9781119385523.ch1. Accessed 15 April 2020.

Jenik PD, Gillmor CS, Lukowitz W. Embryonic patterning in Arabidopsis thaliana. Annu Rev Cell Dev Biol. 2007;23:207-36. https://doi.org/10.1146/annurev. cellbio.22.011105.102609.

Jha P, Kumar V. BABY BOOM (BBM): a candidate transcription factor gene in plant biotechnology. Biotechnol Lett. 2018;40(11-12):1467-75. https://doi.org/10. 1007/s10529-018-2613-5.

Jha P, Ochatt SJ, Kumar V. WUSCHEL: a master regulator in plant growth signaling. Plant Cell Rep. 2020;39:431-44. https://doi.org/10.1007/s00299020-02511-5.

Jia H, McCarty DR, Suzuki M. Distinct roles of LAFL network genes in promoting the embryonic seedling fate in the absence of VAL repression. Plant Physiol. 2013;163:1293-305. https://doi.org/10.1104/pp.113.220988.

Jia H, Suzuki M, McCarty DR. Regulation of the seed to seedling developmental phase transition by the LAFL and VAL transcription factor networks. Wiley Interdiscip Rev Dev Biol. 2014;3:135-45. https://doi.org/10.1002/wdev.126.

Jiménez VM. Involvement of plant hormones and plant growth regulators on in vitro somatic embryogenesis. Plant Growth Regul. 2005;47:91-110. https:// doi.org/10.1007/s10725-005-3478-x .

Jiménez VM, Bangerth F. Endogenous hormone concentrations and embryogenic callus development in wheat. Plant Cell Tissue Organ Cult. 2001;67:37-46. https://doi.org/10.1023/A:1011671310451.

Jiménez VM, Guevara E, Herrera J, et al. Endogenous hormone levels in habituated nucellar Citrus callus during the initial stages of regeneration. Plant Cell Rep. 2001;20:92-100. https://doi.org/10.1007/s002990000280.

Jin S, Zhang Z, Liang S, et al. Factors affecting transformation efficiency of embryogenic callus of upland cotton (Gossypium hirsutum) with Agrobacterium tumefaciens. Plant Cell Tissue Organ Cult. 2005;81:229-37. https://doi.org/10.1007/s11240-004-5209-9

John ME. Cotton improvement through genetic engineering. Crit Rev Biotechnol. 1997;17:185-208. https://doi.org/10.3109/07388559709146613.

Katageri IS, Vamadevaiah HM, Udikeri SS, et al. Genetic transformation of an elite Indian genotype of cotton (Gossypium hirsutum L.) for insect resistance. Curr Sci. 2007;93(12):1843-7.

Keller G, Spatola L, McCabe D, et al. Transgenic cotton resistant to herbicide bialaphos. Transgenic Res. 1997;6:385-92.

Khabbazi SD, Khabbazi AD, Özcan SF, et al. Expression of GNA and biting siterestricted cry $1 \mathrm{Ac}$ in cotton; an efficient attribution to insect pest management strategies. Plant Biotechnol Rep. 2018;12(4):273-82. https://doi. org/10.1007/s11816-018-0493-8

Khan GA, Bakhsh A, Riazuddin S, et al. Introduction of cry1Ab gene into cotton (Gossypium hirsutum) enhances resistance against Lepidopteran pest (Helicoverpa armigera). Span J Agric Res. 2011;9(1):296-302. https://doi.org/ 10.5424/sjar/20110901-136-10

Khan T, Reddy VS, Leelavathi S. High-frequency regeneration via somatic embryogenesis of an elite recalcitrant cotton genotype (Gossypium hirsutum L.) and efficient agrobacterium-mediated transformation. Plant Cell Tiss Organ Cult. 2010;101:323-30. https://doi.org/10.1007/s11240-010-9691-y.

Khanday I, Skinner D, Yang B, et al. A male-expressed rice embryogenic trigger redirected for asexual propagation through seeds. Nature. 2019;565(91-95). https://doi.org/10.1038/s41586-018-0785-8.

Kim HU, Jung SJ, Lee KR, et al. Ectopic overexpression of castor bean LEAFY COTYLEDON2 (LEC2) in Arabidopsis triggers the expression of genes that 
encode regulators of seed maturation and oil body proteins in vegetative tissues. FEBS Open Bio. 2014;4:25-32. https://doi.org/10.1016/j.fob.2013.11.003.

Kim S, Soltis PS, Wall K, et al. Phylogeny and domain evolution in the APETALA2-like gene family. Mol Biol Evol. 2005;23:107-20. https:/doi.org/10.1093/molbev/msj014.

Kulinska-Lukaszek K, Tobojka M, Adamiok A, et al. Expression of the BBM gene during somatic embryogenesis of Arabidopsis thaliana. Biol Plant. 2012;56: 389-94. https://doi.org/10.1007/s10535-012-0105-3.

Kumar $V$, Jha P. Van Staden LEAFY COTYLEDONs (LECs): master regulators in plant embryo development. Plant Cell Tissue Organ Cult. 2020;140:475-87. https://doi.org/10.1007/s11240-019-01752-x.

Kumria R, Sunnichan VG, Das DK, et al. High-frequency somatic embryo production and maturation into normal plants in cotton (Gossypium hirsutum) through metabolic stress. Plant Cell Rep. 2003;21:635-9. https://doi. org/10.1007/s00299-002-0554-9.

Laux T, Würschum T, Breuninger H. Genetic regulation of embryonic pattern formation. Plant Cell. 2004;16:190-202. https://doi.org/10.1105/tpc.016014.

Ledwon A, Gaj M. LEAFY COTYLEDON2 gene expression and auxin treatment in relation to embryogenic capacity of Arabidopsis somatic cells. Plant Cell Rep. 2009:28:1677-88. https://doi.org/10.1007/s00299-009-0767-2.

Leelavathi S, Sunnichan VG, Kumria R, et al. A simple and rapid Agrobacterium-mediated transformation protocol for cotton (Gossypium hirsutum L.): embryogenic calli as a source to generate large numbers of transgenic plants. Plant Cell Rep. 2004;22:465-70. https://doi.org/10.1007/ s00299-003-0710-X.

Leng CX, Li FG, Chen GY. CDNA-AFLP analysis of somatic embryogenesis at early stage in TM-1 (Gossypium hirsutum L.). Acta Bot Boreal-Occident Sin. 2007; 27(2):233-7.

Li KP, Sun XM, Han H, et al. Isolation, characterization and expression analysis of the BABY BOOM (BBM) gene from Larix kaempferi $x$ L. olgensis during adventitious rooting. Gene. 2014;551(2):111-8. https://doi.org/10.1016/j.gene.2014.08.023 .

Lotan T, Ohto M, Yee KM, et al. Arabidopsis LEAFY COTYLEDON1 is sufficient to induce embryo development in vegetative cells. Cell. 1998;93:1195-205. https://doi.org/10.1016/s0092-8674(00)81463-4.

Lowe K, Wu E, Wang N, et al. Morphogenic regulators Baby boom and Wuschel improve monocot transformation. Plant Cell. 2016;28:1998-2015. https://doi. org/10.1105/tpc.16.00124.

Loyola-Vargas VM, Ochoa-Alejo N. Somatic embryogenesis. An overview. In: Loyola-Vargas V, Ochoa-Alejo N, editors. Somatic embryogenesis: fundamental aspects and applications. Dordrech: Springer, Cham; 2016. p. C. 1-8. https://doi.org/10.1007/978-3-319-33705-0_1. Accessed 15 April, 2020

Lutz KA, Martin C, Khairzada S, et al. Steroid-inducible BABY BOOM system for developmental of fertile Arabidopsis thaliana plants after prolonged tissue culture. Plant Cell Rep. 2015;34(10):1849-56. https://doi.org/10.1007/s00299015-1832-7.

Lyon BR, Cousins YL, Llewellyn DJ, et al. Cotton plants transformed with a bacterial degradation gene are protected from accidental spray drift damage by the herbicide 2,4-dichlorophenoxyacetic acid. Transgenic Res. 1993;2:1629. https://doi.org/10.1007/BF01972610.

Majeed A, Husnain T, Riazuddin S. Transformation of virüs resistant genotype of Gossypium hirsutum L. with pesticidal gene. Plant Biotechnol. 2000;17:105-10. https://doi.org/10.5511/plantbiotechnology.17.105.

Mall T, Gupta M, Dhadialla TS, et al. Overview of biotechnology-derived herbicide tolerance and insect resistance traits in plant agriculture. Methods Mol Biol. 2019;1864:313-42. https://doi.org/10.1007/978-1-4939-8778-8_21.

Márquez-López RE, Pérez-Hernández CA, Kú-González Á, et al. Localization and transport of indole3-acetic acid during somatic embryogenesis in Coffea canephora. Protoplasma. 2018;255:695-708. https:/doi.org/10.1007/s00709-017-1181-1

Masters A, Kang M, McCaw M, et al. Agrobacterium-mediated immature embryo transformation of recalcitrant maize inbred lines using Morphogenic genes. J Vis Exp. 2020;156. https://doi.org/10.3791/60782

McCabe DE, Martinell BJ. Transformation of elite cotton cultivars via particle bombardment of meristems. Biotechnol. 1993;11:596-8. https://doi.org/10. 1038/nbt0593-596.

Méndez-Hernández HA, Ledezma-Rodríquez M, Avilez-Montalvo RN, et al. Signaling overview of plant somatic embryogenesis. Front Plant Sci. 2019;10: 77. https://doi.org/10.3389/fpls.2019.00077.

Michalczuk L, Ribnicky DM, Cooke TJ, et al. Regulation of indole-3-acetic acid biosynthetic pathways in carrot cell cultures. Plant Physiol. 1992;100:1346-53. https://doi.org/10.1104/pp.100.3.1346.

Mookan M, Nelson-Vasilchik K, Hague J, et al. Selectable marker independent transformation of recalcitrant maize inbred B73 and sorghum P898012 mediated by morphogenic regulators BABY BOOM and WUSCHEL2. Plant Cell Rep. 2017;36:1477-91. https://doi.org/10.1007/s00299-017-2169-1.

Nic-Can Gl, López-Torres A, Barredo-Pool FA, et al. New insights into somatic embryogenesis: LEAFY COTYLEDON1, BABY BOOM1 and WUSCHELRELATED HOMEOBOX4 are epigenetically regulated in Coffea canephora. PLoS One. 2013;8:e72160. https://doi.org/10.1371/journal.pone.0072160.

Nic-Can GI, Loyola-Vargas VM. The role of the auxins during somatic embryogenesis. In: Loyola-Vargas VM, Ochoa-Alejo N, editors. Somatic embryogenesis. Fundamental aspects and applications. Dordrech: Springer, Cham; 2016. p. 171-81. https://doi.org/10.1007/978-3-319-33705-0_10. Accessed 15 April, 2020.

Ogas J, Kaufmann S, Henderson J, Somerville C. PICKLE is a CHD3 chromatinremodeling factor that regulates the transition from embryonic to vegetative development in Arabidopsis. PNAS. 1999;96:13839-44. https://doi.org/10. 1073/pnas.96.24.13839.

Ohme-Takagi M, Shinshi $\mathrm{H}$. Ethylene-inducible DNA binding proteins that interect with an ethylene-responsive element. Plant Cell. 1995;7:173-82. https://doi. org/10.1105/tpc.7.2.173.

Ooi SE, Choo CN, Ishak Z, Ong-Abdullah M. A candidate auxin-responsive expression marker gene, EgIAA9, for somatic embryogenesis in oil palm (Elaeis guineensis Jacq.). Plant Cell Tissue Organ Cult. 2012;110:201-12. https://doi.org/10.1007/s11240-012-0143-8

Parcy F, Giraudat J. Interactions between the ABI1 and the ectopically expressed ABI3 genes in controlling abscisic acid responses in Arabidopsis vegetative tissues. Plant J. 1997;11:693-702. https:/doi.org/10.1046/j.1365-313x.1997.11040693x.

Parcy F, Valon C, Raynal M, et al. Regulation of gene expression programs during Arabidopsis seed development: roles of the ABI3 locus and of endogenous abscisic acid. Plant Cell. 1994;6:1567-82. https://doi.org/10.1105/tpc.6.11.1567.

Park S, Harada JJ. Arabidopsis embryogenesis. Method Mol Biol. 2008:427:3-16. https://doi.org/10.1007/978-1-59745-273-1_1.

Passarinho $\mathrm{P}$, Ketelaar T, Xing M, et al. BABY BOOM target genes provide diverse entry points into cell proliferation and cell growth pathways. Plant Mol Biol. 2008;68(3):225-37. https://doi.org/10.1007/s11103-008-9364-y.

Pelletier JM, Kwong RW, Park S, et al. LEC1 sequentially regulates the transcription of genes involved in diverse developmental processes during seed development. PNAS. 2017;114:E6710-9. https://doi.org/10.1073/pnas.1707957114.

Pencik A, Tureková V, Paulisiç S, et al. Ammonium regulates embryogenic potential in Cucurbita pepo through $\mathrm{pH}$-mediated changes in endogenous auxin and abscisic acid. Plant Cell Tissue Organ Cult. 2015;122:89-100. https://doi.org/10.1007/s11240-015-0752-0

Pérez-Pascual D, Jiménez-Guillen D, Villanueva-Alonzo H, et al. Ectopic expression of the Coffea canephora SERK1 homolog-induced differential transcription of genes involved in auxin metabolism and in the developmental control of embryogenesis. Physiol Plant. 2018;163:530-51. https://doi.org/10.1111/ppl.12709.

Quiroz-Figueroa FR, Méndez-Zeel M, Sánchez-Teyer F, et al. Differential gene expression in embryogenic and non-embryogenic clusters from cell suspension cultures of Coffea arabica L. J Plant Physiol. 2002;159:1267-70. https://doi.org/10.1078/0176-1617-00878

Quiroz-Figueroa FR, Monforte-González M, Galaz-Ávalos RM, et al. Direct somatic embryogenesis in Coffea canephora. In: Loyola-Vargas VM, Vázquez-Flota FA, editors. Plant cell culture protocols. Methods in molecular biology ${ }^{T M}$. Totowa: Humana Press; 2006. p. 111-7. https://doi.org/10.1385/1-59259-959-1:111 .

Rajasekaran K. Agrobacterium-mediated genetic transformation of cotton. In: Curtis IS, editor. Transgenic crops of the world. Dordrech: Springer; 2004. p. 243-54. https://doi.org/10.1007/978-1-4020-2333-0_18.

Rajasekaran K. Transgenic cotton: methods and protocols. In: Zhang B, editor. Methods in molecular biology. Dordrech: Springer; 2019. p. 19-33. https:// doi.org/10.1007/978-1-4939-8952-2_5

Rajasekaran K, Hudspeth RL, Cary JW, et al. High-frequency stable transformation of cotton (Gossypium hirsutum L.) by particle bombardment of embryogenic cell suspension cultures. Plant Cell Rep. 2000;19:539-45. https://doi.org/10. 1007/s002990050770

Reinert J, Tazawa M, Semenoff S. Nitrogen compounds as factors of the embryogenesis in vitro. Nature. 1967;216:1215-6. https://doi.org/10.1038/ $2161215 \mathrm{a} 0$

Rider SD Jr, Henderson JT, Jerome RE, et al. Coordinate repression of regulators of embryonic identity by PICKLE during germination in Arabidopsis. Plant J. 2003;35(1):33-43.

Riechmann JL, Heard J, Martin G, et al. Arabidopsis transcription factors: genomewide comparative analysis among eukaryotes. Science. 2000;290:2105-10. https://doi.org/10.1126/science.290.5499.2105. 
Sakhanokho HF, Rajasekaran K. Cotton regeneration in vitro. In: Ramawat K, Ahuja $M$, editors. Fiber plants. Sustainable development and biodiversity. Dordrech: Springer, Cham. 2016. p. 87-110. https://doi.org/10.1007/978-3-319-44570-0_ 6 . Accessed 15 April, 2020.

Sattar MN, lqbal Z, Dangol SD, et al. CRISPR/Cas9: a new genome editing tool to accelerate cotton (Gossypium spp.) breeding. In: Al-Khayri JM, Jain SM, Johnson DV, editors. Advances in plant breeding strategies: industrial and food crops. Dordrech: Springer, Cham; 2019. p. 61-84. https://doi.org/10. 1007/978-3-030-23265-8_3

Satyavathi W, Prasad V, Lakshmi BG, et al. High efficiency transformation protocol for three Indian cotton varieties via Agrobacterium tumefaciens. Plant Sci. 2002;162(2):215-23. https://doi.org/10.1016/S0168-9452(01)00547-7.

Shoemaker RC, Couche LJ, Galbraith DW. Characterization of somatic embryogenesis and plant regeneration in cotton (Gossypium hirsutum L.). Plant Cell Rep. 1986;3:178-81. https://doi.org/10.1007/BF00269112.

Silva AT, Barduche D, Livramento $K$, et al. A putative BABY BOOM-like gene (CaBBM) is expressed in embryogenic calli and embryogenic cell suspension culture of Coffea arabica L. In Vitro Cell Dev Biol Plant. 2015;51(1):93-101. https://doi.org/10.1007/s11627-014-9643-z

Smertenko A, Bozhkov PV. Somatic embryogenesis: life and death processes during apical-basal patterning. J Exp Bot. 2014;65:1343-60. https://doi.org/10. 1093/jxb/eru005.

Sood P, Bhattacharya A, Sood A. Problems and possibilities of monocot transformation. Biol Plantarum. 2011;55(1):1-15. https://doi.org/10.1007/ s10535-011-0001-2

Srinivasan C, Liu Z, Heidmann I, et al. Heterologous expression of the BABY BOOM AP2/ERF transcription factor enhances the regeneration capacity of tobacco (Nicotiana tabacum L.). Planta. 2007;225(2):341-51. https://doi.org/10. 1007/s00425-006-0358-1.

Steiner N, Santa-Catarina C, Guerra M, et al. A gymnosperm homolog of SOMATIC EMBRYOGENESIS RECEPTOR-LIKE KINASE-1 (SERK1) is expressed during somatic embryogenesis. Plant Cell Tiss Organ Cult. 2012;109:41-50. https://doi.org/10.1007/s11240-011-0071-z

Stone SL, Kwong LW, Yee KM, et al. Leafy cotyledon encodes a B3 domain transcription factor that induces embryo development. PNAS. 2001;98:1180611. https://doi.org/10.1073/pnas.201413498.

Sun $R$, Tian R, Ma D, et al. Comparative transcriptome study provides insights into acquisition of embryogenic ability in upland cotton during somatic embryogenesis. J Cotton Res. 2018;1(1):9. https:/doi.org/10.1186/s42397-018-0010-1.

Sun R, Wang S, Ma D, et al. Genome-wide analysis of cotton auxin early response gene families and their roles in somatic embryogenesis. Genes. 2019;10:730. https://doi.org/10.3390/genes10100730.

Sung ZR, Okimoto R. Coordinate gene expression during somatic embryogenesis in carrots. PNAS. 1983;80:2661-5.

Sunilkumar G, Rathore KS. Transgenic cotton: factors influencing agrobacteriummediated transformation and regeneration. Molecular Breed. 2001;8(1):37-52. https://doi.org/10.1023/A:1011906701925.

Suzuki M, Wang HH, McCarty DR. Repression of the LEAFY COTYLEDON 1/B3 regulatory network in plant embryo development by VP1/ABSCISIC ACID INSENSITIVE 3-LIKE B3 genes. Plant Physiol. 2007;143:902-11. https://doi.org/ 10.1104/pp.106.092320

Tang FC, Barbacioru C, Wang YZ, et al. mRNA-Seq whole-transcriptome analysis of a single cell. Nat Methods. 2009;6:377-82. https://doi.org/10.1038/nmeth.1315.

Thibaud-Nissen F. Clustering of microarray data reveals transcript patterns associated with somatic embryogenesis in soybean. Plant Physiol. 2003;132: 118-36. https://doi.org/10.1104/pp.103.019968.

Thomas JC, Adams DG, Keppenne VD, et al. Protease inhibitors of Manduca sexta expressed in transgenic cotton. Plant Cell Rep. 1995;14:758-62. https://doi. org/10.1007/BF00232917.

Trontin JF, Klimaszewska K, Morel A, et al. Molecular aspects of conifer zygotic and somatic embryo development: a review of genome-wide approaches and recent insights. In: Germana MA, Lambardi M, editors. In vitro embryogenesis in higher plants. New York: Springer. 2016. p. 167-207. https://doi.org/10.1007/978-1-4939-3061-6_8.

Umbeck P, Johnson G, Barton K, et al. Genetically transformed cotton (Gossypium hirsutum L) plants. Biotechnol. 1987;5:263-6. https://doi.org/10.1038/nbt0387-263.

Wang XW, Luan JB, Li JM, et al. De novo characterization of a whitefly transcriptome and analysis of its gene expression during development. BMC Genomics. 2010;11:400. https://doi.org/10.1186/1471-2164-11-400.

Weinhofer I, Hehenberger E, Roszak P, et al. H3K27me3 profiling of the endosperm implies exclusion of polycomb group protein targeting by DNA methylation. PLoS One. 2010;6(10):e1001152. https://doi.org/10.1371/journal. pgen.1001152.

Wen L, Li W, Parris S, et al. Transcriptomic profiles of non-embryogenic and embryogenic callus cells in a highly regenerative Upland cotton line (Gossypium hirsutum L.). Research Square. 2020; Preprint (Ver 1). https://doi. org/10.21203/rs.3.rs-28441/v1. Accessed 20 August, 2020.

West MAL, Harada JJ. Embryogenesis in higher plants: an overview. Plant Cell. 1993:5:1361-9. https://doi.org/10.1105/tpc.5.10.1361.

Wilkin TA, Mishra R, Trolinder NL. Agrobacterium-mediated transformation and regeneration of cotton. J Food Agric Environ. 2004;2(1):179-87.

Wilkins TA, Rajasekaran K, Anderson DM. Cotton biotechnology. Crit Rev Plant Sci. 2000;19(6):511-50. https://doi.org/10.1080/07352680091139286.

Winkelmann T. Somatic versus zygotic embryogenesis: learning from seeds. In: Germana MA, Lambardi M, editors. In vitro embryogenesis in higher plants. New York: Springer; 2016. p. 25-46. https://doi.org/10.1007/978-1-4939-3061-6_2.

Wójcik AM, Wójcikowska B, Gaj MD. Current perspectives on the auxin-mediated genetic network that controls the induction of somatic embryogenesis in plants. Int J Mol Sci. 2020;21(4):1333. https://doi.org/10.3390/ijms21041333.

Wójcikowska B, Gaj MD. Expression profiling of AUXIN RESPONSE FACTOR genes during somatic embryogenesis induction in Arabidopsis. Plant Cell Rep. 2017; 36:843-58. https://doi.org/10.1007/s00299-017-2114-3 .

Wójcikowska B, Wójcik AM, Gaj MD. Epigenetic regulation of auxin-induced somatic embryogenesis in plants. Int J Mol Sci. 2020;21(7):2307. https://doi. org/10.3390/ijms21072307.

Wu KM, Guo YY. The evolution of cotton pest management practices in China. Annu Rev Entomol. 2005:50:31-52. https:/doi.org/10.1146/annurev.ento.50.071803.130349.

Wu XM, Li FG, Zhang CJ, et al. Differential gene expression of cotton cultivar CCRI24 during somatic embryogenesis. J Plant Physiol. 2009;166:1275-83. https://doi.org/10.1016/j.jplph.2009.01.012.

Yang HF, Kou YP, Gao B, et al. Identification and functional analysis of BABY BOOM genes from Rosa canina. Biol Plant. 2014;58:427-35. https://doi.org/ 10.1007/s10535-014-0420-y

Yang X, Zhang X. Regulation of somatic embryogenesis in higher plants. Crit Rev Plant Sci. 2010;29:36-57. https://doi.org/10.1080/07352680903436291.

Yang $X$, Zhang $X$, Yuan D, et al. Transcript profiling reveals complex auxin signalling pathway and transcription regulation involved in dedifferentiation and redifferentiation during somatic embryogenesis in cotton. BMC Plant Biol. 2012;12:110. https://doi.org/10.1186/1471-2229-12-110.

Zeng FC, Zhang XL, Jin SX, et al. Chromatin reorganization and endogenous auxin/cytokinin dynamic activity during somatic embryogenesis of cultured cotton cell. Plant Cell Tissue Organ Cult. 2007;90:63-70. https://doi.org/10. 1007/s11240-007-9253-0.

Zeng FC, Zhang XL, Zhu LF, et al. Isolation and characterization of genes associated to cotton somatic embryogenesis by suppression subtractive hybridization and macroarray. Plant Mol Biol. 2006;60:167-83. https://doi.org/ 10.1007/s11103-005-3381-x.

Zhang J. Transgenic cotton breeding. Cotton. 2015;57:229-53. https://doi.org/10. 2134/agronmonogr57.2013.0026.

Zhang T, Chen T. Cotton pistil drip transformation method. In: Dunwell J, Wetten A, editors. Transgenic plants. Method in molecular biology (methods and protocols). Totowa: Humana Press; 2012. p. 237-43. https://doi.org/10.1007/ 978-1-61779-558-9_20. Accessed 15 April, 2020.

Zhang Y, Clemens A, Maximova SN, et al. The Theobroma cacao B3 domain transcription factor TCLEC2 plays a duel role in control of embryo development and maturation. BMC Plant Biol. 2014;14:106. https://doi.org/10. 1186/1471-2229-14-106

Zhao P, Begcy K, Dresselhaus T, et al. Does early embryogenesis in eudicots and monocots involve the same mechanism and molecular players? Plant Physiol. 2017:173:130-42. https://doi.org/10.1104/pp.16.01406.

Zheng Y, Ren N, Wang H, et al. Global identification of targets of the Arabidopsis MADS domain protein AGAMOUS-Like15. Plant Cell. 2009;21:2563-77. https://doi.org/10.1105/tpc.109.068890

Zheng ZL, Advani A, Melefors Ö, et al. Titration-free massively parallel pyrosequencing using trace amounts of starting material. Nucleic Acids Res. 2010;38:e137. https://doi.org/10.1093/nar/gkq332.

Zhou T, Yang X, Guo K, et al. ROS homeostasis regulates somatic embryogenesis via the regulation of auxin signaling in cotton. Mol Cell Proteomics. 2016;15: 2108-24. https://doi.org/10.1074/mcp.M115.049338.

Zhu HG, Tu LL, Jin SX, et al. Analysis of genes differentially expressed during initial cellular dedifferentiation in cotton. Chin Sci Bull. 2008;53:3666-76. https://doi.org/10.1007/s11434-008-0468-1. 